Dr. A. N. Khosla was elected president for the next two years; Dr. S. K. Chakravarty was elected vice-president in the vacancy created by the retirement of Sri V. Cadambe; Prof. B. R. Seth was re-elected secretary-treasurer for the next three years ; and Dr. Jai Kishan, Prof. B. Sen Gupta and Prof. D. Banerjee were elected new members of the Executive Committee. The Executive Committee accepted the invitation of the University of Roorkee to hold the fifth Congress in Roorlzee in December 1959.

\section{The Emissivity of the Earth's Surface}

Loss of heat by radiation from the Earth's surface is one of the fundamental physical factors of meteorology. J. T. Houghton (Quart. J. Roy. Meteor. Soc., 84,$448 ; 1958$ ) describes measurements with airborne radiometers at night which permit a comparison to be made between the temperature of the Earth's surface and the black-body temperature of the radiating surface computed from the upward flux of radiation at $200 \mathrm{ft}$. and the temperature and humidity of the intervening atmosphere. At this height about 60 per cent of the upward radiation comes directly from the surface. The observations gave a blackbody temperature between the screen temperature and the ground temperature. Thus on one occasion over north-east Hampshire the effective black-body temperature was $3 \cdot 2^{\circ} \mathrm{C}$., whereas the screen temperature was $4.7^{\circ} \mathrm{C}$. and the ground temperature $2 \cdot 7^{\circ} \mathrm{C}$. It appears that heath and arable lands radiate as black-bodies with an emissivity of 100 per cent. One observation over the English Channel, however, gave an effective temperature about 2 deg. C. higher than the screen and sea temperatures observed nearby at the Royal Sovereign lightship. An observation made just above a layer of stratus cloud at 3,000 ft. gave an emissivity of 100 per cent for the cloud.

\section{A Mongolian Earthquake}

A vioLENT earthquake oceurred on December 4, 1957, in the region of the Gurvan Bogdo mountain chain belonging to the Gobi-Altai system. In January 1958 a joint Mongolian-Russian scientific expedition proceeded to this region, and a brief account of the findings is presented by $\mathbf{N}$. A. Florensov (Priroda, 7, 73; 1958). The region affected by the earthquake is a belt some $270 \mathrm{~km}$. in length containing a system of branching fault fractures, many of them marked by very long fault scarps. The earthquake greatly affected overground and underground waters and the relief of the country.

\section{Powder Patterns of Ferroelectric Domains}

For more than fifty years red lead and sulphur have been used for picking out differently charged portions of the surfaces of insulators. Recently, however, G. L. Pearson and W. L. Feldmann, of the Bell Telephone Laboratories. New York, have used these substances in suspension in hexane to pick out positively and negatively charged domains, respectively, on the surfaces of ferroelectrics. The suspensions are applied separately; one after the other has dried on the surface under investigation. The lead oxide may be replaced by a dispersion of a cross-linked polymer derived from polystyrene. It is also found that colloidal particles of barium titanate, which have a, very high dielectric constant, are deposited at ferroelectric domain boundaries, and this technique has given new information concerning domain structures of a number of ferroelectrics.

\section{Four Rare Indian Animals}

UNTIL 1952 there was no agency in India directly concerned with the preservation of the country's wild life, and the Forest Departments of the various States were able to give only a limited measure of protection within certain of the reserved forests under their jurisdiction. In that year the setting up of the Indian Board for Wild Life to advise the Central Government in New Delhi was an important event in Nature conservation in India. It was followed within a short time by the constitution of State Wild Life Boards in nearly all the States of the Indian Union. Now several States also possess separate Wild Life Departments, within the Forest Department, concerned solely with the preservation of wild life. The creation of these Boards at Central and State levels has not been followed by any remarkable results, nor has there been any marked improvement in the general position of wild life over the whole country. But the publicity given in the Press and elsewhere has succeeded in focusing public attention on the need to protect the country's rare and vanishing species and on the desirability of maintaining and developing wild-life reserves. As a result, writes E. P. Gee (Oryx, 4, No. 2 ; 1958), the status to-day of the Indian rhinoceros, Indian lion, brow-antlered deer and Kashmir stag is more secure than it has been since the lowest recorded levels of these species.

\section{Gordon Childe Memorial Fund}

THE issue of Man of October, 1958, contains an appeal for a Gordon Childe Memorial Fund. Details have not yet been worked out and everything will depend, of course, on the amount of money available. Any friend or admirer of the late Prof. Gordon Childe can send a subscription, now, to the Secretary, University of London Institute of Archæology, 31-34 Gordon Square, London, W.C.1.

\section{Ramsay Memorial Fellowships for Advanced Students of Chemistry}

THE Trustees will consider in June applications for two Ramsay Memorial Fellowships for advanced. students of chemistry. One of the Fellowships will be limited to candidates educated in Glasgow, who can apply to be considered for either Fellowship. The value of each Fellowship will be $£ 600$ per annum, to which may be added a grant for expenses of research not exceeding $£ 100$ per annum. The Fellowships will normally be tenable for two years. Full particulars can be obtained from the Joint Honorary Secretaries, Ramsay Memorial Fellowships Trust, University College, Gower Street, London, W.C.l. Completed application forms must be received not later than April 13.

\section{Mond Nickel Fellowships}

MOND NICKEL FeLlowships are intended to enable selected British graduates to obtain additional training and wider experience in industrial establishments, in Britain or abroad, so that, if they are afterwards employed in executive or administrative positions in the British metallurgical industries, they will be better qualified to appreciate the technological significance of research and to apply its results. It is also hoped that the training facilities provided will attract persons qualified in sciences other than metallurgy into the metallurgical field. Fach Fellowship will occupy one full working year; 